\title{
Review
}

\section{Medication Trends for Age-Related Macular Degeneration}

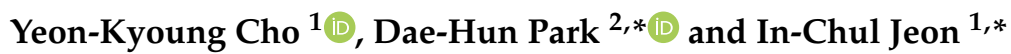 \\ 1 College of Health and Welfare, Dongshin University, Naju 58245, Jeonnam, Korea; yktender@naver.com \\ 2 College of Korean Medicine, Dongshin University, Naju 58245, Jeonnam, Korea \\ * Correspondence: dhj1221@hanmail.net (D.-H.P.); icjeon@dsu.ac.kr (I.-C.J.)
}

Citation: Cho, Y.-K.; Park, D.-H.; Jeon, I.-C. Medication Trends for Age-Related Macular Degeneration. Int. J. Mol. Sci. 2021, 22, 11837. https://doi.org/10.3390/ijms 222111837

Academic Editor: Jae Youl Cho

Received: 12 October 2021

Accepted: 29 October 2021

Published: 31 October 2021

Publisher's Note: MDPI stays neutral with regard to jurisdictional claims in published maps and institutional affiliations.

Copyright: (c) 2021 by the authors. Licensee MDPI, Basel, Switzerland. This article is an open access article distributed under the terms and conditions of the Creative Commons Attribution (CC BY) license (https:/ / creativecommons.org/licenses/by/ $4.0 /)$.

\begin{abstract}
Age-related macular degeneration (AMD) is central vision loss with aging, was the fourth main cause of blindness in 2015, and has many risk factors, such as cataract surgery, cigarette smoking, family history, hypertension, obesity, long-term smart device usage, etc. AMD is classified into three categories: normal AMD, early AMD, and late AMD, based on angiogenesis in the retina, and can be determined by bis-retinoid $N$-retinyl- $N$-retinylidene ethanolamine (A2E)-epoxides from the reaction of $\mathrm{A} 2 \mathrm{E}$ and blue light. During the reaction of $\mathrm{A} 2 \mathrm{E}$ and blue light, reactive oxygen species (ROS) are synthesized, which gather inflammatory factors, induce carbonyl stress, and finally stimulate the death of retinal pigment epitheliums (RPEs). There are several medications for AMD, such as device-based therapy, anti-inflammatory drugs, anti-VEGFs, and natural products. For device-based therapy, two methods are used: prophylactic laser therapy (photocoagulation laser therapy) and photodynamic therapy. Anti-inflammatory drugs consist of corticosteroids and non-steroidal antiinflammatory drugs (NSAIDs). Anti-VEGFs are classified antibodies for VEGF, aptamer, soluble receptor, VEGF receptor-1 and -2 antibody, and VEGF receptor tyrosine kinase inhibitor. Finally, additional AMD drug candidates are derived from natural products. For each medication, there are several and severe adverse effects, but natural products have a potency as AMD drugs, as they have been used as culinary materials and/or traditional medicines for a long time. Their major application route is oral administration, and they can be combined with device-based therapy, anti-inflammatory drugs, and anti-VEGFs. In general, AMD drug candidates from natural products are more effective at treating early and intermediate AMD. However, further study is needed to evaluate their efficacy and to investigate their therapeutic mechanisms.
\end{abstract}

Keywords: age-related macular degeneration (AMD); medication; device-based therapy; antiinflammatory drugs; anti-VEGFs; natural products

\section{Introduction \\ 1.1. Definition}

Age-related macular degeneration (AMD) is related to aging and is a disease that causes problems in the central region of the retina, also known as the macula [1]. AMD patients experience several physiological changes, such as the loss of central vision, drusen, retinal pigmentary changes, angiogenesis, etc., and according to angiogenesis in the retina, it can be classified as dry AMD or wet AMD, with the percentage of wet AMD cases reported to be $10-15 \%$ of the total AMD cases [2].

\subsection{Health Problems, Statistics, and Risk Factors}

In 2015, AMD was the fourth most common cause of blindness, and among patients with moderate to severe vision impairment, it was the third most common cause [3]. Among those aged 80 years and above, $66 \%$ have several signs of AMD [4,5], and 3\% of those over 65 years old suffer visual problems caused by AMD [6]. According to Zou's study on the global burden of AMD from 1990 to 2017, special groups can significantly suffer from AMD, such as females, the elderly, those from developing countries, and low-educated persons, etc., and from 1990 to 2017, AMD contributed to a doubling of the 
number of people living a low quality of life [7]. An even more serious consideration is that the number of global AMD patients has been predicted to rise from 196 million in 2020 to 288 million in 2040 [8].

There are many risk factors associated with AMD, such as tobacco smoking, age increasing, experiences of cataract surgery, family history, high body mass index (BMI) values, cardiovascular disease, hypertension, plasma fibrinogen, obesity, atherosclerosis, high-density lipoprotein cholesterol (HDC-C), etc. [9-12]. Furthermore, as smart device use grows, ophthalmological problems can come to the fore, especially the probability of AMD occurrence, which might be caused by increases in smartphones' blue light $[13,14]$; for this reason, a reduction in the smartphone usage of children and juveniles has been recommended [15].

\subsection{Classification of Current Medication}

Currently, there are several types of AMD medication (Table 1), including devicebased treatment (prophylactic laser or photocoagulation therapy, photodynamic therapy), anti-inflammatory drug treatment (corticosteroids, nonsteroidal anti-inflammatory drugs (NSAIDs)), anti-vascular endothelial growth factor (anti-VEGF) intravitreal injection, nutritional therapy (antioxidants, $\omega-3$ fatty acids, lutein, zeaxanthin, long-chain polyunsaturated fatty acids, plant extracts, etc.), etc. We discuss here the current AMD medications and their advantages and disadvantages, and consider how to prevent or improve the symptoms of intermediate AMD.

Table 1. The categories of AMD medication.

\section{Category}

Device-based treatment

Anti-inflammatory drug treatment

Anti-vascular endothelial growth factor (VEGF) treatment

Nutritional treatment

\section{Description}

(1) Prophylactic laser therapy (or photocoagulation therapy) is to eliminate the drusen.

(2) Photodynamic therapy is to block the choroidal neovascularization simultaneously using a photosensitizer.

(1) Corticosteroid drugs completely block the inflammatory pathway via phospholipase A2 inactivation.

(2) Nonsteroidal anti-inflammatory drugs (NSAIDs) inhibit the activation of cyclooxygenase (COX-1, COX-2) to make prostaglandins (PGs) or/and lipoxygenase to make leukotrienes.

(1) VEGF antibodies bind on VEGF and then inhibit VEGF activation.

(2) Aptamer binds on VEGF in a manner similar to VEGF antibodies.

(3) Soluble VEGF receptors bind on VEGF instead of VEGF receptors.

(4) Anti-VEGF receptors (-1 or -2) bind VEGF receptors for blocking VEGF's binding to VEGF receptors.

(5) Tyrosine kinase inhibitors control the pathway following VEGF binding on VEGF receptors.

According to the therapeutic mechanism, nutritional treatments can be classified below

(1) Inhibition of oxidative stress and apoptosis;

(2) Inhibition of inflammation and apoptosis;

(3) Inhibition of oxidative stress, inflammation, and apoptosis;

(4) Inhibition of apoptosis;

(5) Inhibition of pyroptosis;

(6) Inhibition of carbonyl stress;

(7) Inhibition of $\mathrm{G}_{2} / \mathrm{M}$ phase arrest;

(8) Inhibition of VEGF activation.

\section{Age-Related Macular Degeneration (AMD)}

\subsection{Category}

AMD can be classified into two types: early (dry) AMD and late (wet, exudative) AMD, depending on the angiogenesis or lack thereof in the retina. In order to harmonize the classification of AMD in 2014, researchers from three continents reported that according to the sizes and types of areas of drusen, early AMD can be categorized into three types: 
mild early AMD, moderate early AMD, and severe early AMD. Late AMD can be classified as geographic atrophy or neovascular AMD and can be defined by the occurrence of atrophy, the formation of new blood vessels in the retina, pigment epithelial detachment and/or retinal detachment, etc. [16].

\subsection{Pathogenic Factors}

With advancing years, lipofuscin, also called aging pigments, accumulates in several cells after mitosis, such as neurons, cardiac cells, and retinal pigment epithelium (RPE), and bis-retinoid $N$-retinyl- $N$-retinylidene ethanolamine (A2E) are two of the main causes of lipofuscin in our body [17]. A2E accumulation in our body is an aging phenomenon, and although the mechanism behind it is unclear, it is vulnerable to oxidative damage [18]. A2E is very fickle, and it depends on the wavelength of light and the A2E oxidation form induced by blue light (480 $\pm 20 \mathrm{~nm})$ [19]; A2E-epoxides induce cell damage and then finally stimulate cell death [20]. In RPE cells, A2E treatment has been reported to increase the level of VEGF mRNA and protein but did not affect the expression of vascular endothelial growth factor receptor 1 (VEGFR1) or VEGFR2. However, blue light exposure in A2E-loaded cells stimulated VEGFR1 but not the levels of VEGF mRNA and protein [21]. Blue light is in the special range (400-500 nm) of visible light, and in 1978, Ham and his colleagues reported that short wavelength light-i.e., blue light, not temperature-induced photochemical damage in rhesus macaques' retinal pigment epithelium [22].

\subsection{Pathogenesis}

Oxidation is a chemical reaction that involves both the loss and simultaneous reduction in electrons in molecules [23]. Oxidation both positively and negatively affects bio-organisms: it beneficially affects them through eradicating foreign pathogenic microorganisms and modulating the function of enzymes and transcription factors via phosphorylation or dephosphorylation [24], but it damages them through breaking their cell membranes and cellular organelles and then finally inducing many chronic diseases [25-27]. Inflammation is the result of bio-organisms' defense mechanisms; in innate immunity, many inflammatory cells, such as eosinophils, basophils, neutrophils, monocytes, lymphocytes, etc., accumulate in the infestation site to eliminate foreign bodies via chemotaxis [28], but if a given immune system cannot overcome an invasion of foreign bodies, inflammatory products such as enzymes (elastase, collagenase, etc.) and immune mediators (cytokines, chemokines, etc.) finally stimulate cellular damage and cell death. Inflammatory cells stimulate the release of reactive species at the inflammation site; consequently, the level of reactive species increases $[29,30]$. On the other hand, reactive species stimulate the release of pro-inflammatory cytokines, such as TGF- $\beta$, IL-1, etc., through activating transcription factors such as NF- $\mathrm{k}$, AP-1, and HIF-1 $\alpha$ [31]. Carbonyl stress results from proteins that have been changed to carbonyl compounds and autoxidized by carbohydrates, lipids, or amino acids. Carbonyl compounds are called advanced glycosylation end products (AGEs). There are carbohydrate-derived AGEs, such as 3-deoxyglucosone, o-arabinose, and glyoxalate; polyunsaturated fatty acid-derived ones, such as malondialdehyde and hydroxyinonenal; an ascorbic acid-derived one, dehydroascorbate; and amino acid-derived ones, such as acrolein and 2-hydroxyipropanal [32].

In RPE apoptosis and oxidative stress, carbonyl stress and inflammation have a very important cause-and-effect relationship. Compared with the other tissues in the body, the level of PUFA in the RPE is very high, and RPE cells are more vulnerable to oxidative stress and carbonyl stress [33]. Especially in AMD patients, the levels of ROS such as nitrotyrosine, $\mathrm{H}_{2} \mathrm{O}_{2}, \mathrm{Cu} / \mathrm{Zn}$-superoxide dismutase (SOD1), and Mn-superoxide dismutase (SOD2) (but not NO [34-38]); AGEs such as malondialdehyde (MDA), 4-hydroxynonenal (4-HNE), malonaldehyde-bis-dimethyl acetal, 4-hydroxyhexenal (4-HHE), protein carbonyl content [38-42]; inflammatory cytokines such as IL-1 $\beta$ and IL-2, IL-6, IL-18, TNF- $\alpha$ via NLRP3 $[39,41,43]$ are significantly increased, and eventually they induce RPE apoptosis via 
the activation of calpain-1, caspase-3, and caspase-9 and the modulation of Fas/Fas ligand (FasL), NF-kB activation, and Bax and Bad [33,44-46].

\section{Device-Based Treatment}

\subsection{Prophylactic Laser Therapy (Photocoagulation Laser Therapy)}

Bruch's membrane, which supports the blood stream by stimulating the retina's functions from the choroid layer, is located close to the RPE, but with advancing years, drusen, which are lipid-rich deposits (lipofuscin), not only accumulate between the RPE and Bruch's membrane but also grow in size. Then, if the RPE cannot be supplied blood from the choroid layer, it faces death (apoptosis) [47,48]. Drusen are a hallmark for comparing the grades of AMD, and according to their size and distribution, AMD, including three early AMD stages, can be classified into five categories: no AMD, mild early AMD, moderate early AMD, severe early AMD, and late AMD [16] (Table 2).

Table 2. The stage classification of age-related macular degeneration (AMD) depending on the drusen size and distribution area (from Klein 2014 [16]).

\begin{tabular}{|c|c|}
\hline Category & Description \\
\hline No AMD & $\begin{array}{l}\text { No drusen, or questionable, small, or intermediate sized drusen }(<125 \mu \mathrm{M} \text { in diameter) only, } \\
\text { regardless of area of involvement, and no pigmentary abnormalities (defined as increased } \\
\text { retinal pigment or RPE depigmentation present) } \\
\text { OR } \\
\text { no definite drusen with any pigmentary abnormality. }\end{array}$ \\
\hline Mild early AMD & $\begin{array}{l}\text { Small to intermediate sized drusen }(<125 \mu \mathrm{M} \text { in diameter), regardless of area of } \\
\text { involvement, with any pigmentary abnormality, } \\
\text { OR }\end{array}$ \\
\hline Moderate early AMD & $\begin{array}{c}\text { Large drusen }(\geq 125 \mu \mathrm{M} \text { in diameter }) \text {, with drusen area }<331,820 \mu \mathrm{m}^{2} \text { and any } \\
\text { pigmentary abnormality, } \\
\text { OR } \\
\text { large drusen }(\geq 125 \mu \mathrm{M} \text { in diameter }) \text {, with drusen area } \geq 331,820 \mu \mathrm{m}^{2}, \text { with or without } \\
\text { increased retinal pigment but with no RPE depigmentation. }\end{array}$ \\
\hline Severe early AMD & $\begin{array}{l}\text { Large drusen ( } \geq 125 \mu \mathrm{M} \text { in diameter), with drusen area } \geq 331,820 \mu \mathrm{m}^{2} \text { and } \mathrm{RPE} \\
\text { depigmentation present, with or without increased retinal pigment. }\end{array}$ \\
\hline Late AMD & $\begin{array}{l}\text { Pure geographic atrophy in the absence of exudative macular degeneration } \\
\text { OR } \\
\text { exudative macular degeneration, with or without geographic atrophy present. }\end{array}$ \\
\hline
\end{tabular}

AMD, age-related macular degeneration; RPE, retinal pigment epithelium.

Prophylactic laser therapy is similar to photocoagulation therapy. They both involve resolving drusen using laser treatment. The mechanism of drusen resolution by laser treatment is very simple, as laser beams have enough energy (heat) to burn drusen (Figure 1).

In 1973, the first study results on photocoagulation effects on the eyes depending on laser usage were reported, and according to the results of the study, argon laser irradiation could resolve the drusen in the eye [49]. However, if thermal lasers can be applied to drusen resolution, their heat could induce the death of RPEs near the irradiated drusen [50]. Frennesson and Nilsson [51] reported the beneficial effects of low power photocoagulation laser therapy, which affects the death of RPEs less than the high power therapy. Subthreshold diode laser treatment has been tried for suppressing AMD progress, but its application has not been well established [52]. In order to decrease the thermal effects that induce RPE death and to increase drusen resolution, prophylactic laser therapy continues to be developed. Recently, in order to avoid subordinate damage, such as RPE death, nanosecond pulse laser therapy has been developed [53]. The nanosecond pulse laser method can be 
precisely applied to drusen, and it has been found to be capable of resolving drusen only. The prophylactic laser therapeutics are summarized in Table 3.

Early AMD

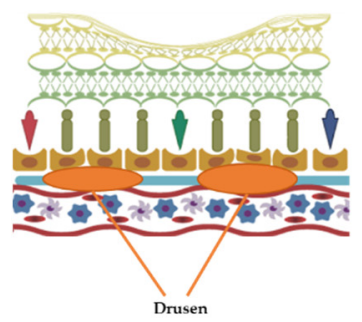

Drusen Resolution

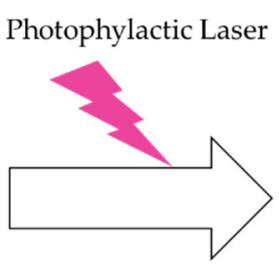

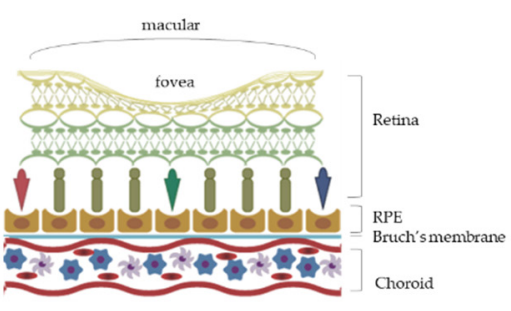

Figure 1. The mechanism of prophylactic laser therapy (photocoagulation therapy). In the early AMD stage, the drusen in Bruch's membrane inhibit the blood supply to the RPE and eliminate the wastes near that area, such as lipofuscin (A2E). Finally, the accumulation of drusen in this area induces RPE death and worsens AMD. With energy (heat), prophylactic laser therapy resolves the build-up of drusen and then suppresses AMD progress.

Table 3. Summary of the prophylactic/photocoagulation laser therapeutics.

\begin{tabular}{ccc}
\hline Classification of Laser & Advantage and Disadvantage & Reference \\
\hline Xenon or Ruby in 1973 & Resolves drusen but induces RPE death. & {$[49]$} \\
Argon Green (Low power) in 1998 & Decreases RPE death but insufficiently. & {$[51]$} \\
Subthreshold diode in 2006 & Decreases AMD progress but is not well established. & {$[52]$} \\
Nanosecond Pulse in 2011 & Applies precise titration. & {$[53]$} \\
\hline
\end{tabular}

\subsection{Photodynamic Therapy}

Photomedicine can be defined as medical processes that use light for the diagnosis of and treatment of disease [54], and photochemotherapy can be classified into two categories, depending on the source of photosensitizers. One category is endogenous photosensitizers, which can absorb the light in the human body, and the other category is exogenous photosensitizers, which should be injected into the patient to accelerate their consumption of light from a medical device. The mechanisms of photodynamic therapy can be classified into three categories: anti-angiogenesis effects caused by thrombosis and stasis, anticancer effects caused by oxidative stress enhancement, and immune system modulation effects [55-57] (Figure 2).

There are many records of the use of sunlight for healing patients [58], and in the 19th century, Finsen tried to eliminate smallpox and lupus vulgaris using sunlight's bactericidal effect [57]. In 1903, the first clinical trial was conducted for curing cancer, psoriasis, lupus vulgaris, etc., using topical eosin under sunlight and arc irradiation, but this study was withdrawn because of pain and scar formation [59]. In 1948, using red fluorescent light tumor analysis and therapy, a study was conducted [60], and after the 1970s, hematoporphyrin derivatives $(\mathrm{HpD})$, especially Photofrin ${ }^{\circledR}$, were widely used for curing cancers, such as lung and esophagus cancers [61].

In order to destroy choroidal neovascularization (CNV) in AMD patients, liposomal verteporfin is widely used as a photosensitizer for its photodynamic therapeutic effects; patients should be irradiated by $689 \mathrm{~nm}$ light for 5 minutes after liposomal verteporfin intravenous injection [57]. However, during this therapy, an adverse effect that can damage the normal choriocapillaries has been reported; there have been many trials since to develop new photosensitizers to reduce this adverse effect [62-64]. 


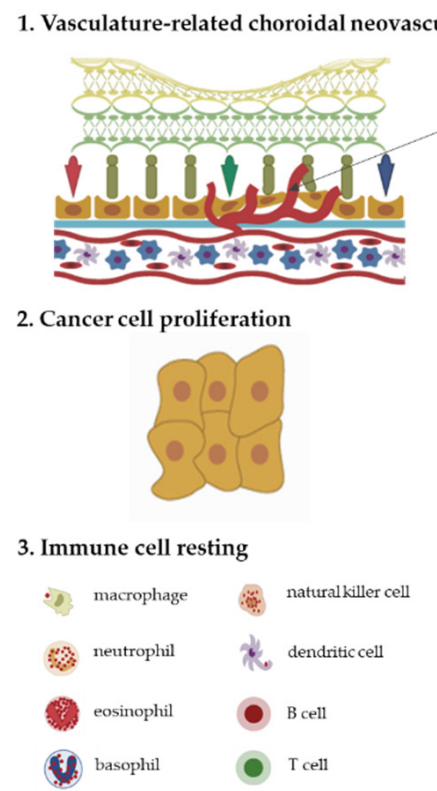
vessel
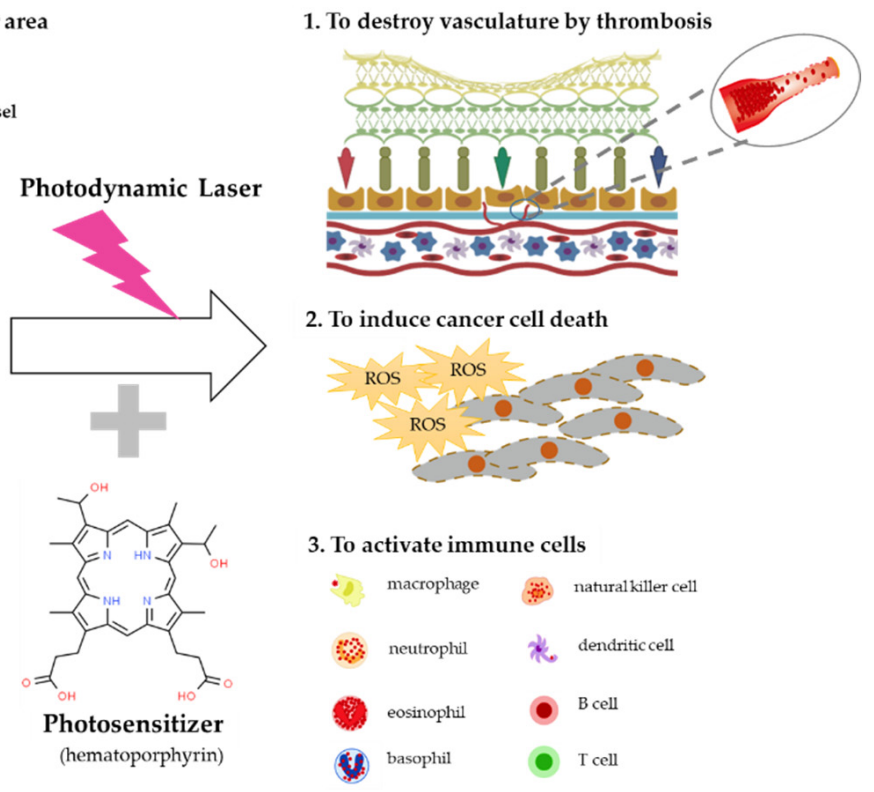

Figure 2. The mechanisms of photodynamic therapy. Photodynamic therapy generates reactive oxygen species (ROS) and destroys photosensitizer-binding fast proliferative cells, such as choroidal neovascularization (CNV) cells related to AMD via thrombosis and cancer cells through ROS synthesis, and stimulates immune cells' activation.

\section{Anti-Inflammatory Drugs}

Drusen is one of the hallmarks for diagnosing AMD, as they are made by the destruction of RPE cells with advancing years, and the inflammation is closely related to AMD progress, as that produces drusen [65]. It is important to suppress inflammation progress to inhibit the severity of AMD (late AMD), and as shown Figure 3, there is an antiinflammatory pathway caused by corticosteroid drugs and nonsteroidal anti-inflammatory drugs (NSAIDs).
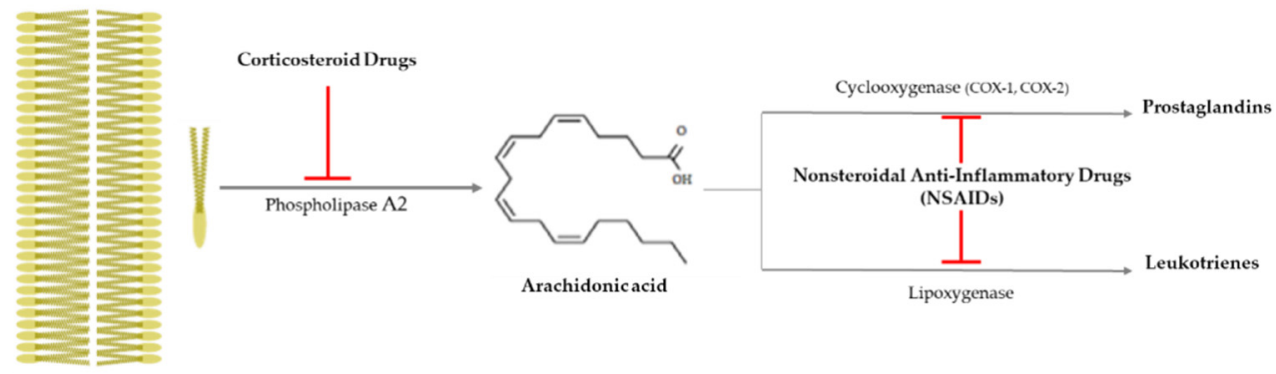

Figure 3. Anti-inflammatory pathway caused by corticosteroid drugs and nonsteroidal antiinflammatory drugs (NSAIDs). Corticosteroid drugs inhibit the formation of arachidonic acid by causing plasma membrane breakage, which is caused by phospholipase $\mathrm{A}_{2}$. On the other hand, nonsteroidal anti-inflammatory drugs (NSAIDs) only control arachidonic acid and prostaglandins through cyclooxygenase 1 or 2 (COX-1 or -2$)$. - t: to inhibit the follow action. COX, cyclooxygenase.

In 2008, an epidemiological study on the relation between anti-inflammatory drug use and AMD occurrence was conducted based on 614 patients (the average age and standard deviation, $72.9 \pm 6.8$ ) and 4,526 normal veterans (the average age and standard deviation, $73.2 \pm 6.7$ ) from 1997 to 2001 [66]. According to the study's results, antiinflammatory drug use suppressed the occurrent risk of AMD. As the macrophage-derived proinflammatory cytokines such as tumor necrosis factor- $\alpha$ (TNF- $\alpha$ ) and interleukin-1 (IL-1) especially increase when Bruch's membrane is destroyed, and as they stimulate the increment of vascular endothelial cells, anti-inflammatory drugs can effectively suppress 
AMD progress [67]. In Table 4, anti-inflammatory drugs that are used in AMD treatment are summarized.

Table 4. Summary of anti-inflammatory drugs for AMD treatment.

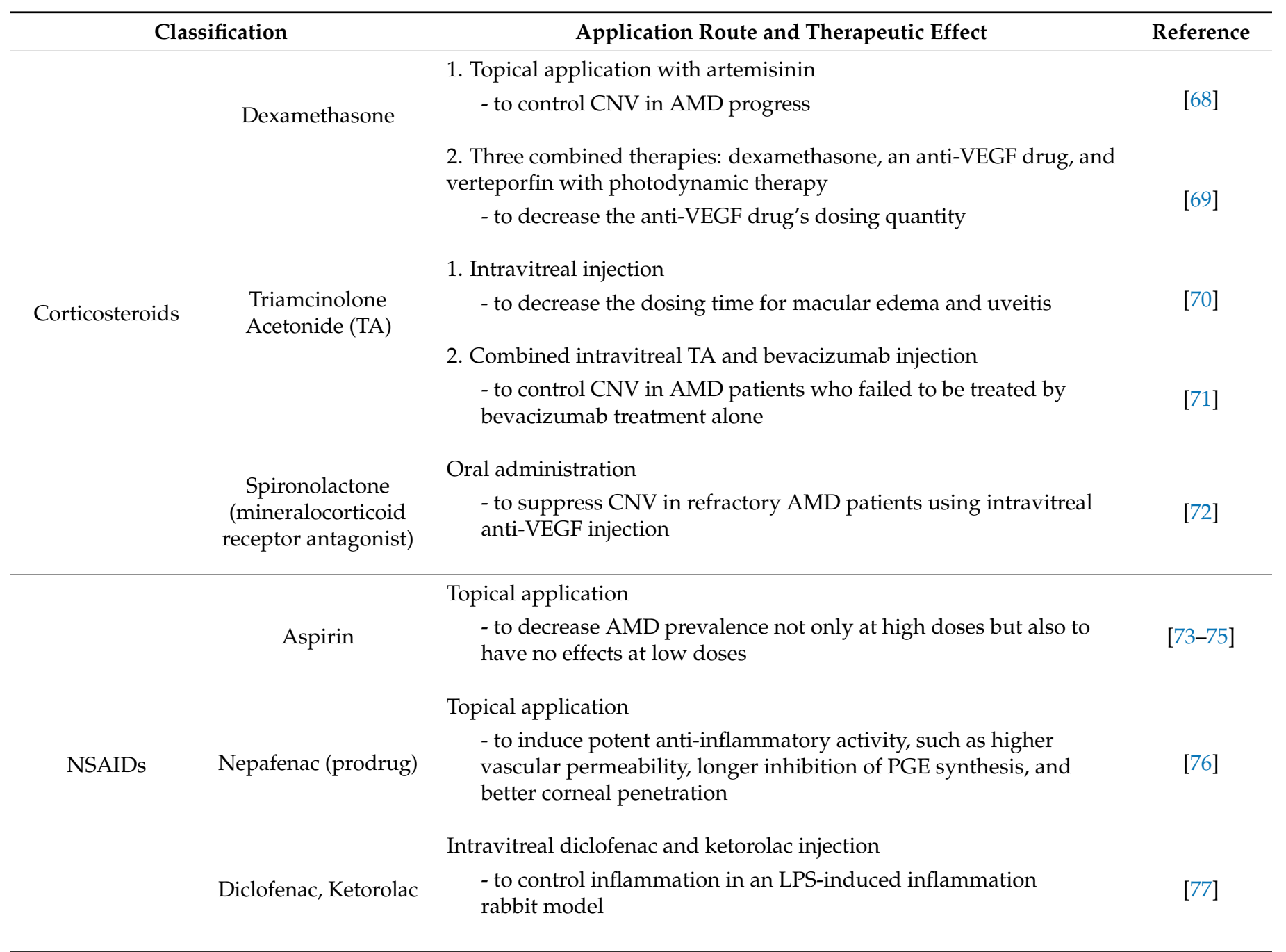

NSAIDs, nonsteroidal anti-inflammatory drugs; CNV, choroidal neovascularization; AMD, age-related macular degeneration; VEGF, vascular endothelial growth factor; TA, triamcinolone acetonide; LPS, lipopolysaccharide.

\subsection{Corticosteroid Drugs}

Corticosteroid drugs can perfectly inhibit the inflammation occurrence pathway, as they significantly control the arachidonic acid synthesis from plasma membrane breakage using phospholipase $\mathrm{A}_{2}$ [78] (Figure 3). Topical nanodispersion of dexamethasone and artemisinin on the eyeball effectively control CNV in AMD progress [68], and triple therapy using dexamethasone, bevacizumab, and verteporfin with photodynamic therapy is one of the anti-vascularization therapies used for AMD [69]. Triamcinolone acetonide (TA) has been widely used as a drug for macular edema and uveitis, as its effective duration is longer than that of dexamethasone [70], and combined intravitreal triamcinolone acetonide and bevacizumab injection has provided treatment to AMD patients who failed to be treated by the intravitreal injection of bevacizumab alone [71]. Spironolactone is a mineralocorticoid receptor antagonist that can be orally administered, and it is used to effectively suppress CNV in patients refractory to intravitreal anti-VEGF injections [72]. 


\subsection{Nonsteroidal Anti-Inflammatory Drugs (NSAIDs)}

Nonsteroidal anti-inflammatory drugs (NSAIDs) inhibit the synthesis of prostaglandins (PGEs) via inactivating cycloxygenase-1 (COX-1) or cycloxygenase-2 (COX-2), and they have been used as anti-inflammatory and antipyretic agents and analgesic drugs [78] (Figure 3). They are used as topical applicants for various ophthalmological purposes-for example, as an inflammation suppressor against allergic conjunctivitis and keratitis, a down-regulator for cystoid macular edema, a contractor for cataract surgery, etc. [79]. Aspirin is a famous NSAID, but although a low aspirin dose has been found to not affect AMD occurrence [73,74], a high aspirin dose might decrease AMD prevalence [75]. Nepafenac is a potent NSAID prodrug that has higher vascular permeability, longer inhibition of PGE synthesis, and better corneal penetration than others [76]. Intravitreal diclofenac and ketorolac injections have been found to effectively control inflammation in a lipopolysaccharide (LPS)-induced ocular inflammation rabbit model [77].

\section{Anti-Vascular Endothelial Growth Factor (Anti-VEGF)}

Vascularization is one of the most important aspects of AMD progress and severity, and anti-CNV therapy is an important strategy for controlling AMD. VEGF is the first inducer to be found that can stimulate sprouting angiogenesis from vascular endothelial cells and the permeability of vessels [80], and it is synthesized in ganglion, Muller, and RPE cells [81], as it is much more selective to vascular endothelial cells [82]. There are several VEGFs, including VEGF-A, VEGF-B, VEGF-C, VEGF-D, VEGF-E, and placental growth factor (PGF), and the molecular weight range of VEGFs is between 35 and 45 $\mathrm{kd}$ homodimers [82]. In particular, the hypoxic condition in the retina promotes VEGF excretion, and released VEGF induces pathologic angiogenesis, called CNV in AMD. Then, leaked fluid from them leads to blindness by increasing the intraocular pressure via edema, exudation, and hemorrhage in the retina area [83].

It is possible to classify the inhibitors into six groups: (1) VEGF antibodies (humanized ones, such as bevacizumab (Avastin ${ }^{\mathrm{TM}}$ ), or fragment of humanized ones, such as ranibizumab (Lucentis $\left.{ }^{\mathrm{TM}}\right)$ ); (2) aptamers (oligonucleotides such as Pegaptanib ${ }^{\mathrm{TM}}$ ); (3) soluble receptors (aflibercept (Eylea $\left.{ }^{\mathrm{TM}}\right)$ ); (4) anti-VEGF-R1; (5) anti-VEGF-R2; and (6) VEGFR tyrosine kinase inhibitors, such as imatinib mesylate, sorafenib, sunitinib, and vatalanib in CNV (Figure 4).

It is difficult to cure wet and exudate AMD, but recently, various drugs for inhibiting CNV have been developed [82,84-86]. The most developed anti-VEGF drugs directly control VEGF activation, inhibiting the VEFG function for such a long time that they only need to be administered every 2 months [87]. In Table 5, the currently used antiVEGF drugs are summarized. Humanized antibodies for VEGF, such as bevacizumab (Avastin ${ }^{\mathrm{TM}}$; Genentech, South San Francisco, CA, USA), which is a monoclonal full-length antibody, and ranibizumab (Lucentis ${ }^{\mathrm{TM}}$; Genetech), which is a monoclonal fragment (Fab) antibody, bind all active forms of VEGF [86,88]. In the RPE, two active forms of VEGF-A exist in high quantities: VEGF 165 and VEGF $_{121}$ [89], and VEGF aptamers such as pegaptinib (Macugen ${ }^{\mathrm{TM}}$; Pfizer, New York, NY, USA) only bind VEGF 165 , inhibiting $\mathrm{VEGF}_{165}$ activation [90]. Aflibercept (Eylea ${ }^{\mathrm{TM}}$; Regeneron Pharmaceuticals Inc., Tarrytown, NY, USA) is a soluble VEGF receptor that binds to all circulating VEGFs, such as VEGF-A, $-B,-C,-D,-E$, and PGF, and then traps them in order to inactivate them, similar to VEGF traps $[91,92]$. 


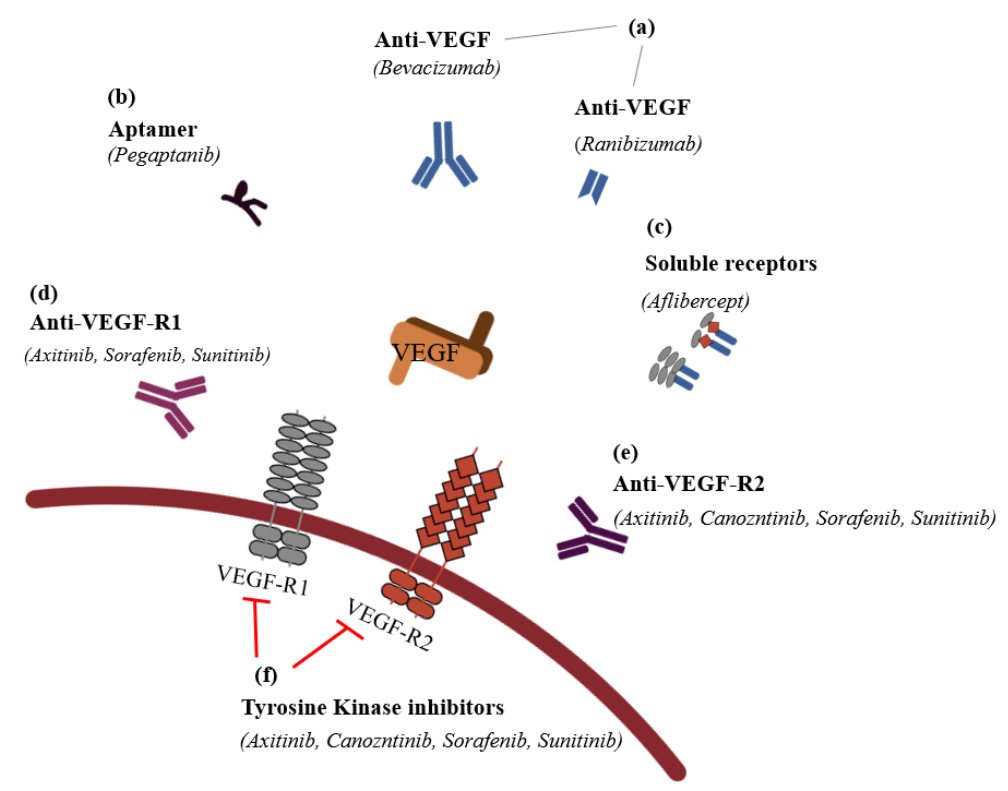

Figure 4. The classification of anti-vascular endothelial growth factors (modified from Noel et al., 2007 [84]). (a) VEGF antibodies directly bind the VEGF to inhibit its activation; these antibodies include humanized antibodies, such as bevacizumab (Avastin ${ }^{\mathrm{TM}}$ ), and fragment of humanized antibodies, such as ranibizumab (Lucentis ${ }^{\mathrm{TM}}$ ). (b) Apamers adhere on the VEGF to act like VEGF antibodies, and pegaptanib (Macugen ${ }^{\mathrm{TM}}$ ) is the representative drug in this category. (c) In order to serve VEGF's function, soluble receptors should bind on VEGF receptor-1 or -2, but if instead of binding VEGF receptors, VEGF adheres on exogeneous and artificial VEGF receptors (VEGF trap), such as aflibercept (Eylea ${ }^{\mathrm{TM}}$ ), they cannot serve an angiogenesis function in the vascular endothelial cell. Anti-VEGF receptor 1 (d) and anti-VEGF receptor 2 (e) are receptors for VEGF, but if anti-VEGF-R1 and -R2 bind their receptors, VEGF cannot neovascularize. (f) If VEGFR tyrosine kinase inhibitors such as imatinib mesylate, sorafenib, sunitinib, and vatalanib inhibit the following process after VEGF's binding, the CNV of VEGF receptors cannot occur. - - : to inhibit the follow action. VEGF, vascular endothelial growth factor; VEGF-R1, vascular endothelial growth factor receptor 1; VEGF-R2, vascular endothelial growth factor receptor 2.

Table 5. Summary of the currently used anti-vascular endothelial growth factor (anti-VEGF) drugs for AMD treatment.

\begin{tabular}{|c|c|c|c|c|c|}
\hline \multicolumn{2}{|c|}{ Classification } & Inhibits & Half-Life & Doses & Reference \\
\hline \multirow{2}{*}{ VEGF Antibody } & $\begin{array}{c}\text { Humanized Ab: } \\
\text { bevacizumab (Avastin }{ }^{\mathrm{TM}} \text {; } \\
\text { Genentech, South San } \\
\text { Francisco, CA, USA) }\end{array}$ & $\begin{array}{l}\text { All VEGF-A } \\
\text { isoforms }\end{array}$ & $4 \sim 5$ days & $1.25 \mathrm{mg} / \mathrm{month}$ & [85] \\
\hline & $\begin{array}{l}\text { Fragment Humanized Ab: } \\
\text { Ranibizumab (Lucentis }{ }^{\mathrm{TM}} \\
\text { Genentech, South San } \\
\text { Francisco, CA, USA) }\end{array}$ & $\begin{array}{l}\text { All VEGF-A } \\
\text { isoforms }\end{array}$ & $6 \sim 10$ days & $0.5 \mathrm{mg} / \mathrm{month}$ & [85] \\
\hline Aptamer & $\begin{array}{c}\text { Pegaptanib (Macugen }{ }^{\mathrm{TM}} \text {; } \\
\text { Pfizer, New York, NY, USA) }\end{array}$ & $\begin{array}{l}\text { VEGF-A } 165 \\
\text { isoform }\end{array}$ & $8 \sim 14$ days & $\begin{array}{l}0.3 \mathrm{mg} / \mathrm{two} \\
\text { months }\end{array}$ & [90] \\
\hline Soluble Receptor & $\begin{array}{c}\text { Aflibercept (Eylea }{ }^{\mathrm{TM}} ; \\
\text { Regeneron Pharmaceuticals } \\
\text { Inc., Tarrytown, NY, USA) }\end{array}$ & $\begin{array}{c}\text { All VEGF-A } \\
\text { isoforms, VEGF-B, } \\
\text { PGF }\end{array}$ & $5 \sim 6$ days & $2 \mathrm{mg} /$ two month & [91] \\
\hline
\end{tabular}

VEGF, vascular endothelial growth factor; PGF, placental growth factor.

Recently, there have been many reports on VEGF receptor inhibitors and VEGF tyrosine kinase inhibitors, and, to date, many studies have been conducted to confirm the possibility of AMD treatment, with some exceptions. However, there are several VEGF re- 
ceptor inhibitors, such as axitinib (Inlyta ${ }^{\circledR}$; Pfizer, Inc., New York, NY, USA) [93,94], cabozntinib (Cabometyx ${ }^{\circledR}$; Exelixis Pharmaceuticals, Inc., Alameda, CA, USA) [95], sorafenib (Nexavar $^{\circledR}$; LC Laboratories, Woburn, MA, USA) [96,97], SU11248/sunitinib (Sutent ${ }^{\circledR}$; Pfizer, Inc., New York, NY, USA) [98], and VEGF receptor tyrosine kinase inhibitors, such as axitinib $\left(\right.$ Inlyta $\left.^{\circledR}\right)[93,94]$, cabozntinib (Cabometyx ${ }^{\circledR}$ ) [95], sorafenib $\left(\right.$ Nexavar $\left.^{\circledR}\right)[96,97]$, and SU11248/sunitinib (Sutent ${ }^{\circledR}$; Pfizer, Inc., New York, NY, USA) [98]. Furthermore, a past cancer study found that axitinib (Inlyta ${ }^{\circledR}$ ) acts on all VEGF receptor inhibitors and on VEGF receptor tyrosine kinase inhibitor [93], and Kang et al. illuminated its anti-angiogenic potency as an agent for AMD treatment based on a mouse study [94]. Cabozntinib (Cabomety ${ }^{\circledR}$ ) was intravitreally applied into mice for anti-angiogenesis in a mouse model, and effectively down-regulated both VEGF receptor 2 activation and VEGF tyrosine kinase activation [95]. Sorafenib (Nexavar ${ }^{\circledR}$ ) inhibits not only the activation of VEGFR-1 and VEGFR-2 but also the activation of VEGF receptor tyrosine kinase [96,97]. A biocompatibility study of the effects of multikinase inhibitors such as pazopanib, sorafenib (Nexavar $\left.{ }^{\circledR}\right)$, and axitinib (Inlyta ${ }^{\circledR}$ ) on human ocular cells found that, for all the inhibitors, there were no toxic effects until $7.5 \mu \mathrm{g} / \mathrm{mL}$; when the cells were treated with 7.5 $\mu \mathrm{g} / \mathrm{mL}$ or more of the inhibitors, the order of the effects on cell viability was pazopanib, sorafenib (Nexavar ${ }^{\circledR}$ ), and axitinib (Inlyta ${ }^{\circledR}$ ) [97]. SU11248/sunitinib (Sutent ${ }^{\circledR}$ ) acts both as a VEGF receptor-2 inhibitor and a multitargeted tyrosine kinase receptor inhibitor, and its ability to treat AMD was confirmed based on a mouse model [98] and a chicken chorioallantoic membrane (CAM) model [99]. Table 6 shows a summary of the developed anti-VEGF drugs.

Table 6. Summary of the developed anti-vascular endothelial growth factor (anti-VEGF) drugs for AMD treatment.

\begin{tabular}{|c|c|c|c|c|c|c|c|}
\hline \multirow{2}{*}{ Agent } & \multicolumn{3}{|c|}{$\begin{array}{l}\text { Inhibition Point } \\
\text { (Mode of Action) }\end{array}$} & \multicolumn{3}{|c|}{ Application } & \multirow{2}{*}{ References } \\
\hline & VEGF R-1 & VEGF R-2 & $\begin{array}{l}\text { Tyrosine } \\
\text { Kinase }\end{array}$ & Model & Route & Dose & \\
\hline $\begin{array}{c}\text { Axitinib } \\
\text { (Inlyta }^{\circledR} ; \text { Pfizer, Inc., } \\
\text { New York, NY. USA) }\end{array}$ & 0 & $\bigcirc$ & $\bigcirc$ & Mouse & P.O. & $5 \mathrm{mg} / \mathrm{kg}$ & [94] \\
\hline $\begin{array}{c}{\text { Sorafenib }\left(\text { Nexavar }^{\circledR}\right.}^{\circledR} \\
\text { LC Laboratories, } \\
\text { Woburn, MA, USA) }\end{array}$ & 0 & 0 & 0 & RPE cell & Media & $1 \mu \mathrm{g} / \mathrm{mL}$ & {$[96,97]$} \\
\hline \multirow[b]{2}{*}{$\begin{array}{l}\text { Sunitinib or SU11248 } \\
\text { (Sutent }^{\circledR} \text {; Pfizer Inc., } \\
\text { New York, NY, USA) }\end{array}$} & \multirow{2}{*}{0} & \multirow{2}{*}{0} & \multirow{2}{*}{$\bigcirc$} & Mouse & P.O. & $80 \mathrm{mg} / \mathrm{kg}$ & [98] \\
\hline & & & & $\begin{array}{l}\text { Chicken } \\
\text { chorioallantoic } \\
\text { membrane } \\
(\mathrm{CAM})\end{array}$ & Topical & $\begin{array}{c}20 \mu \mathrm{L} \text { of } \\
20 \mu \mathrm{M}\end{array}$ & [99] \\
\hline $\begin{array}{c}\text { Cabozntinib } \\
\left(\text { Cabometyx }^{\circledR} ; \text {; Exelixis }\right. \\
\text { Pharmaceuticals, Inc., } \\
\text { Alameda, CA, USA) }\end{array}$ & - & 0 & 0 & Mouse & Intravitreal & $2 \mu \mathrm{g} /$ head & [95] \\
\hline
\end{tabular}

\section{Drug Candidates Originated from Natural Products}

Lutein and zeaxanthin exist as meso-zeaxanthin (a dipolar form, dihydroxylated carotenoid) in the retina, called macular xanthophylls, [100] which are included in dark green leafy vegetables such as kale, spinach, peas, etc. and egg yolks [101], and they suppress phototoxicity-induced oxidative stress and apoptosis in the visual system [102] and also induce $\mathrm{G}_{2} / \mathrm{M}$ phase arrest in the RPE [103]. Recently, there have been many trials that have investigated AMD drug candidates from natural products, with these products especially studied for their ability to regulate the RPE's status (Table 7). These natural product candidates can be classified into (1) anti-apoptosis inducers, (2) cell cycle arrest 
modulators, and (3) VEGF inactivators. Based on the apoptotic pathway, the candidates can be grouped into (1) anti-oxidative stress, (2) anti-inflammation, and (3) anti-carbonyl stress candidates. One hundred percent EtOH extract of Arctium lappa L. leaves has been found to have plentiful amounts of phenolics and flavonoids, and it effectively suppressed both oxidative stress by scavenging effects of 2,2-diphenyl-1-picrylhydrazyl (DPPH) and 2,2'-azino-bis(3-ethylbenzothiazoline-6-sulfonic acid)(ABTS) and apoptosis by modulating bcl-2 family and caspase cascade [104]. Genipin is a glycosidic ligand that has been found to suppress $\mathrm{H}_{2} \mathrm{O}_{2}$-induced oxidative stress and apoptosis via nuclear factor-erythroid 2-related factor-2 (Nrf2), which regulates the expression of heme oxygenase-1 (HO-1) and $\mathrm{NAD}(\mathrm{P}) \mathrm{H}$ : quinine oxidoreductase 1 (NQOA) [105]. Delphinidin is one of the anthocyanins that exists in several fruits and vegetables [106] and has been found to significantly inhibit the synthesis of reactive oxygen species (ROS) through modulating antioxidative enzyme activation and apoptosis via regulating the bcl-2 family and caspase cascade [107]. Glabridin (isoflavonoid) from Glycyrrhiza glabra L. root has been demonstrated to inhibit oxidative stress and apoptosis through ERK1/2 and p38MAPK inactivation [108]. Wogonin (5,7-dihydroxy-8-methoxyflavone), isolated from Scutellaria baicalensis Georgi root, has been found to control LPS-induced inflammation changes such as IL-1 $\beta$, IL-6, IL-8, TNF- $\alpha$, COX-2, and inducible nitric oxide synthase (iNOS) via the Toll-like receptor 4 (TLR4)/NFКB pathway [109]. Hot water extract of Prunella vulgaris var. L has been observed to prevent oxidative stress by ROS generation, carbonyl stress by MDA production, and inflammation through Nrf2/HO-1 pathway [110]. Vaccinium uliginosum L. hot water extract has been found to suppress A2E- and blue light-induced apoptosis by controlling caspase cascade and bcl-2 pathway [111]. Baicalin, a flavonoid isolated from Scutellaria baicalensis Georgi, has been found to inhibit $A \beta$-induced pyroptosis through modulating miR-223/NLRP3 inflammasome pathway [112]. $\beta$-carotene, as a typical carotenoid, has anti-oxidative effects and is one of the major components in tomatoes (Lycopersicum esculentum L.) [113] and has been reported to down-regulate $\mathrm{H}_{2} \mathrm{O}_{2}$-induced nitrotyrosine formation and protein carbonylation [38]. Bile acid is synthesized in the liver (primary bile acid) and in the colon (secondary bile acid), and is known as bile salt when it is conjugated with taurine or glycine [114]; the major bile salts include taurocholic acid, glycocholic acid, taurochenodeoxycholic acid, and glycochenodeoxycholic acid, etc. [115], and taurocholic acid, one of the major bile salts, has been demonstrated to inhibit angiogenesis-related cell proliferation, cell migration, and tube formation [116].

Table 7. Summary of AMD drug candidates developed from natural products.

\begin{tabular}{|c|c|c|c|c|c|c|c|}
\hline \multirow{2}{*}{$\begin{array}{l}\text { Therapeutic } \\
\text { Mechanism }\end{array}$} & \multicolumn{3}{|c|}{ Natural Product } & \multicolumn{3}{|c|}{ Application } & \multirow[b]{2}{*}{ References } \\
\hline & Species & $\begin{array}{c}\text { Applied } \\
\text { Characteristic }\end{array}$ & $\begin{array}{c}\text { Effective } \\
\text { Compound }\end{array}$ & Model & Route & $\begin{array}{c}\text { Minimum } \\
\text { Effective Dose }\end{array}$ & \\
\hline \multirow{6}{*}{$\begin{array}{l}\text { Inhibition of } \\
\text { oxidative stress } \\
\text { and apoptosis }\end{array}$} & \multirow{2}{*}{$\begin{array}{c}\text { Arctium lappa } \mathrm{L} . \\
\text { leaf }\end{array}$} & \multirow{2}{*}{$\begin{array}{c}100 \% \text { EtOH } \\
\text { extract }\end{array}$} & \multirow{2}{*}{$\begin{array}{c}\text { Phenolic and } \\
\text { flavonoid }\end{array}$} & RPE cell & Media & $30 \mu \mathrm{g} / \mathrm{mL}$ for $24 \mathrm{~h}$ & \multirow{2}{*}{ [104] } \\
\hline & & & & Mouse & I.P. & $50 \mathrm{mg} / \mathrm{kg}$ for $4 \mathrm{w}$ & \\
\hline & $\begin{array}{l}\text { Eucommia } \\
\text { ulmoides }\end{array}$ & $\begin{array}{l}\text { Genipin } \\
\text { (glycosidic } \\
\text { ligand) }\end{array}$ & $\begin{array}{l}\text { Genipin } \\
\text { (glycosidic } \\
\text { ligand) }\end{array}$ & ARPE-19 cell & Media & $30 \mu \mathrm{M}$ for $24 \mathrm{~h}$ & [105] \\
\hline & $\begin{array}{c}\text { Fruit or } \\
\text { Vegetable }\end{array}$ & $\begin{array}{c}\text { Delphinidin } \\
\text { (anthocyanidin) }\end{array}$ & $\begin{array}{c}\text { Delphinidin } \\
\text { (anthocyanidin) }\end{array}$ & ARPE-19 cell & Media & $25 \mu \mathrm{g} / \mathrm{mL}$ for $24 \mathrm{~h}$ & [107] \\
\hline & \multirow{2}{*}{$\begin{array}{l}\text { Glycyrrhiza } \\
\text { glabra L. root }\end{array}$} & \multirow{2}{*}{$\begin{array}{c}\text { Glabridin } \\
\text { (isoflavonoid) }\end{array}$} & \multirow{2}{*}{$\begin{array}{c}\text { Glabridin } \\
\text { (isoflavonoid) }\end{array}$} & RPE cell & Media & $2 \mu \mathrm{M}$ for $2 \mathrm{~h}$ & \multirow{2}{*}{ [108] } \\
\hline & & & & Mouse & I.P. & $20 \mathrm{mg} / \mathrm{kg}$ for $1 \mathrm{w}$ & \\
\hline $\begin{array}{l}\text { Inhibition of } \\
\text { inflammation } \\
\text { and apoptosis }\end{array}$ & $\begin{array}{l}\text { Scutellaria } \\
\text { baicalensis } \\
\text { Georgi root }\end{array}$ & $\begin{array}{l}\text { 5,7-dihydroxy-8- } \\
\text { methoxyflavone } \\
\text { (wogonin) }\end{array}$ & $\begin{array}{l}\text { 5,7-dihydroxy-8- } \\
\text { methoxyflavone } \\
\text { (wogonin) }\end{array}$ & ARPE-19 cell & Media & $10 \mu \mathrm{M}$ for $24 \mathrm{~h}$ & [109] \\
\hline \multirow{2}{*}{$\begin{array}{c}\text { Inhibition of } \\
\text { oxidative stress, } \\
\text { inflammation, } \\
\text { and apoptosis }\end{array}$} & \multirow{2}{*}{$\begin{array}{c}\text { Prunella } \\
\text { vulgaris var. L }\end{array}$} & \multirow{2}{*}{ Water extract } & \multirow{2}{*}{ Rosmarinic Acid } & ARPE-19 cell & Media & $100 \mu \mathrm{g} / \mathrm{mL}$ for $24 \mathrm{~h}$ & \multirow{2}{*}{ [110] } \\
\hline & & & & Mouse & P.O. & $100 \mathrm{mg} / \mathrm{kg}$ for 4 day & \\
\hline $\begin{array}{c}\text { Inhibition of } \\
\text { apoptosis }\end{array}$ & $\begin{array}{l}\text { Vaccinium } \\
\text { uliginosum } \mathrm{L}\end{array}$ & Water extract & Polyphenol & ARPE-19 cell & Media & $100 \mu \mathrm{g} / \mathrm{mL}$ for $24 \mathrm{~h}$ & [111] \\
\hline
\end{tabular}


Table 7. Cont.

\begin{tabular}{|c|c|c|c|c|c|c|c|}
\hline \multirow[b]{2}{*}{$\begin{array}{l}\text { Therapeutic } \\
\text { Mechanism }\end{array}$} & \multicolumn{3}{|c|}{ Natural Product } & \multicolumn{3}{|c|}{ Application } & \multirow[b]{2}{*}{ References } \\
\hline & Species & $\begin{array}{c}\text { Applied } \\
\text { Characteristic }\end{array}$ & $\begin{array}{l}\text { Effective } \\
\text { Compound }\end{array}$ & Model & Route & $\begin{array}{l}\text { Minimum } \\
\text { Effective Dose }\end{array}$ & \\
\hline $\begin{array}{l}\text { Inhibition of } \\
\text { pyroptosis }\end{array}$ & $\begin{array}{c}\text { Scutellaria } \\
\text { baicalensis } \\
\text { Georgi }\end{array}$ & Baicalin & Baicalin & ARPE-19 cell & Media & $50 \mu \mathrm{g} / \mathrm{mL}$ for $72 \mathrm{~h}$ & [112] \\
\hline $\begin{array}{l}\text { Inhibition of } \\
\text { carbonyl stress }\end{array}$ & $\begin{array}{l}\text { Lycopersicum } \\
\text { esculentum L. } \\
\text { (Tomato) }\end{array}$ & n-hexane extract & $\beta$-carotene & ARPE-19 cell & Media & $\begin{array}{c}1 \mu \mathrm{M} \text { - } \beta \text {-carotene } \\
\text { for } 24 \mathrm{~h}\end{array}$ & [38] \\
\hline $\begin{array}{l}\text { Inhibition of } \\
\mathrm{G}_{2} / \mathrm{M} \text { phase } \\
\text { arrest }\end{array}$ & $\begin{array}{l}\text { Fruit or } \\
\text { Vegetable }\end{array}$ & Lutein & Lutein & ARPE-19 cell & Media & $25 \mu \mathrm{g} / \mathrm{mL}$ for $24 \mathrm{~h}$ & [103] \\
\hline \multirow{2}{*}{$\begin{array}{c}\text { Inhibition of } \\
\text { VEGF activation }\end{array}$} & \multirow{2}{*}{$\begin{array}{l}\text { Bile Acid } \\
\text { (Animal) }\end{array}$} & \multirow{2}{*}{ Taurocholic acid } & \multirow{2}{*}{ Taurocholic acid } & HRPEpiC cell & \multirow{2}{*}{ Media } & \multirow{2}{*}{$100 \mu \mathrm{M}$ for $48 \mathrm{~h}$} & \multirow{2}{*}{ [116] } \\
\hline & & & & RF/6A cell & & & \\
\hline
\end{tabular}

RPE, retinal pigment epithelium; I.P., intraperitoneal injection; w, week; EtOH, ethanol; ARPE-19, adult retinal pigment epithelial cell line-19; P.O., oral administration; HRPEpiC, human retinal pigment epithelial cells; RF/6A, chorioretinal cells from Rhesus macaque (non-human primate).

\section{Perspectives}

AMD, which was the third main cause of blindness in 2015 [3], is related to aging [1], and recently, its rate has increased considerably as birth rates have rapidly decreased. In 2017, the United Nations reported that the population of those 60 years old and over constituted 962 million people, more than twice (382 million) that recorded in 1980, with this demographic projected to be double (2.1 billion) the number recorded in 2017 [117] by 2050. In particular, the 60-year-old and over demographic's share of the total population, which was about $20 \%$ in 2017, is expected to reach $35 \%$ in 2050. The prevalence of AMDinduced vision problems, therefore, is predicted to become much higher in the years to come. Along with aging, many factors can cause AMD, such as smoking, cataract surgery, $\mathrm{BMI}$, cardiovascular problems, hypertension, fibrinogen, atherosclerosis, HDC-C, and the blue light of smart devices [9-14].

Although there are several medications for AMD, there are none that cure AMD perfectly without adverse effects. Device-based treatments, such as prophylactic laser therapy and photodynamic therapy, are very useful methods, as they involve noninvasive therapy, but, because these lasers use very high temperatures, if a prophylactic laser's or photocoagulation laser's curing point is wrong, these methods can damage the visual cells in the eye, such as macular edema, and lead to retinovascular diseases, among others $[118,119]$. Further, the most important problem of photodynamic therapy is its nonspecificity to cells, which means that photodynamic therapy can attack normal cells [120]. Therapies that use anti-inflammatory drugs such as corticosteroids or NAIDs are very useful for inhibiting inflammation and angiogenesis in AMD, but because corticosteroids have many adverse effects, such as hypertension, insulin resistance, insomnia, irritability, purpura, skin thinning, cataracts, glaucoma, gastric ulceration, etc. [121], their usage is limited to combined treatments with photodynamic therapy or anti-VEGF drugs; furthermore, as NSAIDs' long-term therapeutic efficacy is unclear, more studies are needed [122]. Recently, anti-VEGF therapy has proven to be the most useful treatment method for AMD, as it has been found to inhibit angiogenesis from between one month and two months [85,90-92], but it has several adverse effects, such as bleeding and infection risk from intravitreal injection, the detachment of the retina, RPE tears, vitreoretinal fibrosis, etc. [123,124].

AMD is one of the incurable diseases; thus, it is most important to prevent its severity [1]. Although the prevalence rate of AMD increases with age, if we can prevent AMD from progressing to more severe forms, we can lower the population prevalence of blindness. From this reason, many natural products that can possibly constrain AMD severity have been used and investigated. Based on their modes of action, they can be divided into those that are preventers of RPE death/cell cycle arrest (anti-apoptosis inducers and cell 
cycle arrest modulators) $[104,105,107-112]$ and those that are inhibitors of VEGF activation (VEGF inactivators) [38]. Natural products are safer than synthetic chemicals, as they have been used for a long time, they have an easy route of administration, with most able to be orally applied, and they can be used as combined therapies, such as with device-based therapy, anti-inflammatory drugs, and anti-VEGF molecules. We can conclude that AMD drug candidates from natural products can be applied to treat early and intermediate AMD [10].

Funding: This research received no external funding.

Conflicts of Interest: The authors declare no conflict of interest.

\section{References}

1. Bhutto, I.; Lutty, G. Understanding age-related macular degeneration (AMD): Relationships between the photoreceptor/retinal pigment epithelium/Bruch's Membrane/choriocapillaris complex. Mol. Aspects Med. 2012, 33, 295-317. [CrossRef]

2. Khandhadia, S.; Cherry, J.; Lotery, A.J. Age-related macular degeneration. Adv. Exp. Med. Biol. 2012, 724, 15-36. [PubMed]

3. Jonas, J.B.; Cheung, C.M.G.; Panda-Jonas, S. Updates on the epidemiology of age-related macular degeneration. Asia-Pac. J. Ophthalmol. 2017, 6, 493-497.

4. Friedman, D.S.; O'Colmain, B.J.; Munoz, B.; Tomany, S.C.; Macarty, C.; de Jong, P.T.V.M.; Nemesure, B.; Mitchell, P.; Kempen, J.; Congdon, N. Prevalence of age-related macular degeneration in the United States. Arch. Ophthalmol. 2004, 122, 564-572.

5. Bressler, N.M. Age-related macular degeneration is the leading cause of blindness. JAMA 2004, 291, 1900-1901. [CrossRef]

6. Seland, J.H.; Vingerling, J.R.; Augood, C.A.; Bentham, G.; Chakravarthy, U.; de Jong, P.T.V.M.; Rahu, M.; Soubrane, G.; Tomazzoli, L.; Topouzis, F.; et al. Visual impairment and quality of life in the older European population, the EUREYE study. Acta Ophthalmol. 2011, 89, 608-613. [CrossRef]

7. Zou, M.; Zhang, Y.; Chen, A.; Young, C.A.; Li, Y.; Zheng, D.; Jin, G. Variations and trends in global disease burden of age-related macular degeneration: 1990-2017. Acta Ophthalmol. 2021, 99, e330-e335. [CrossRef]

8. Wong, W.L.; Su, X.; Li, X.; Cheung, C.M.G.; Klein, R.; Cheng, C.Y.; Wong, T.Y. Global prevalence of age-related macular degeneration and disease burden projection for 2020 and 2040: A systematic review and meta-analysis. Lancet Glob. Health 2014, 2, e106-e116. [CrossRef]

9. Chakravarthy, U.; Wong, T.Y.; Fletcher, A.; Piault, E.; Evans, C.; Zlateva, G.; Buggage, R.; Pleil, A.; Mitchell, P. Clinical risk factors for age-related macular degeneration: A systematic review and meta-analysis. BMC Ophthalmol. 2010, 10, 31. [CrossRef] [PubMed]

10. Garcia-Layana, A.; Cabrera-Lopez, F.; Garcia-Arumi, J.; Arias-Barquet, L.; Ruiz-Moreno, J.M. Early and intermediate age-related macular degeneration: Update and clinical review. Clin. Interv. Aging. 2017, 12, 1579-1587. [CrossRef] [PubMed]

11. Fan, Q.; Maranville, J.C.; Fritsche, L.; Sim, X.; Cheng, C.M.G.; Chen, L.J.; Gorski, M.; Yamashiro, K.; Ahn, J.; Laude, A.; et al. HDLcholesterol levels and risk of age-related macular degeneration: A multiethnic genetic study using Mendelian randomization. Int. J. Epidemiol. 2017, 46, 1891-1902. [CrossRef] [PubMed]

12. Zhang, Q.-Y.; Tie, L.-J.; Wu, S.-S.; Lv, P.-L.; Huang, H.-W.; Wang, W.-Q.; Wang, H.; Ma, L. Overweight, obesity and risk of age-related macular degeneration. Investig. Ophthalmol. Vis. Sci. 2016, 57, 1276-1283. [CrossRef] [PubMed]

13. Jang, Y.J.; Ha, J.M.; Park, S.-I. Cell death derived from photooxidation of A2E by irradiating using smart device in retinal pigment epithelial cells. J. Korean Ophthalmic. Opt. Soc. 2020, 25, 421-426. [CrossRef]

14. Moon, J.; Yun, J.; Yoon, Y.D.; Park, S.I.; Seo, Y.J.; Park, W.S.; Kang, J.S. Blue light effect on retinal pigment epithelial cells by display devices. Integr. Biol. 2017, 9, 436-443. [CrossRef]

15. Oeverhaus, M.; Hirche, H.; Esser, J.; Eckstein, A.; Schaperdoth-Gerlings, B. Evaluation of the medical treatment situation of the visually impaired: Significant differences between young and old. Ophthalmology 2019, 116, 164-171. [CrossRef]

16. Klein, R.; Meuer, S.M.; Myers, C.E.; Buitendijk, G.H.S.; Rochtchina, E.; Choudhury, F.; Klein, B.E.K. Harmonizing the classification of age-related macular degeneration in the three continent AMD consortium. Ophthalmic. Epidemiol. 2014, 21, 14-23. [CrossRef]

17. Crouch, R.K.; Koutalos, Y.; Kono, M.; Schey, K.; Ablonczy, Z. A2E and lipofuscin. Prog. Mol. Biol. Transl. Sci. 2015, 134, 449-463. [PubMed]

18. Yin, D. Biochemical basis of lipofuscin, ceroid, and age pigment-like fluorophores. Free Radic. Biol. Med. 1996, 21, 871-888. [CrossRef]

19. Sparrow, J.R.; Nakanishi, K.; Parish, C.A. The lipofuscin fluorophore A2E mediates blue light-induced damage to retinal pigmented epithelial cells. Investig. Ophthalmol. Vis. Sci. 2000, 41, 1981-1989.

20. Sparrow, J.R.; Vollmer-Snarr, H.R.; Zhou, J.; Jockusch, S.; Itagaki, Y.; Nakanishi, K. A2E-epoxides damage DNA in retinal pigment epithelial cells. Int. J. Biol. Chem. 2003, 278, 18207-18213. [CrossRef] [PubMed]

21. Marie, M.; Gondouin, P.; Pagan, D.; Barrau, C.; Villette, T.; Sahel, J.; Picaud, S. Blue-violet light decreases VEGF a production in an in vitro model of AMD. PLoS ONE 2019, 14, e0223839. [CrossRef]

22. Ham, W.T., Jr.; Ruffolo, J.J., Jr.; Mueller, H.A.; Clarke, A.M.; Moon, M.E. Histologic analysis of photochemical lesions produced in rhesus retina by short-wave-length light. Investig. Ophthalmol. Vis. Sci. 1978, 17, 1029-1035. 
23. Mayes, P.A.; Botham, K.M. Biologic Oxidation. In Harper's Illustrated Biochemistry; Murray, R.K., Granner, D.K., Mayes, P.A., Rodwell, V.W., Eds.; McGraw-Hill: Noida, India, 2003; pp. 86-91.

24. Halliwell, B. Reactive species and antioxidants, Redox biology is a fundamental theme of aerobic life. Plant. Physiol. 2006, 141, 312-322. [CrossRef]

25. Biswas, S.K.; Lopes de Faria, J.B. Hypertension induces oxidative stress but not macrophage infiltration in the kidney in the early stage of experimental diabetes mellitus. J. Nephrol. 2006, 26, 415-422. [CrossRef]

26. Ambade, A.; Mandrekar, P. Oxidative stress and inflammation: Essential partners in alcoholic liver disease. Int. J. Hepatol. 2012. [CrossRef]

27. Cachofeiro, V.; Goicochea, M.; Garcia de Vinuesa, S.; Oubina, P.; Lahera, V.; Luno, J. Oxidative stress and inflammation, a link between chronic kidney disease and cardiovascular disease. Kidney. Int. 2008, 74, S4-S9. [CrossRef] [PubMed]

28. Biswas, S.K. Does the interdependence between oxidative stress and inflammation explain the antioxidant paradox? Oxid. Med. Cell. Logev. 2016, 2016, 5698931. [CrossRef]

29. Collins, T. Acute and chronic inflammation. In Robbins Pathologic Basis of Disease; Cotran Kumar, V., Collins, T., Eds.; W.B. Saunders: Philadelphia, PA, USA, 1999; pp. 50-88.

30. Mittal, M.; Siddiqui, M.R.; Tran, K.; Reddy, S.P.; Malik, A.B. Reactive oxygen species in inflammation and tissue injury. Antioxid. Redox. Singal. 2014, 20, 1126-1167. [CrossRef] [PubMed]

31. Chatterjee, S. chapter two. oxidative stress, inflammation, and disease. In Oxidative Stress and Biomaterials; Dzuibla, T., Butterfield, D.A., Eds.; Academic Press: London, UK, 2016; pp. 35-58.

32. Zoccali, C.; Mallamaci, F.; Tripepi, G. AGEs and carbonyl stress: Potential pathogenetic factors of long-term uraemic complications. Nephrol. Dial. Transplant. 2000, 15 (Suppl. 2), 7-11. [CrossRef]

33. Bazan, N.G. Survival signaling in retinal pigment epithelial cells in response to oxidative stress: Significance in retinal degenerations. Adv. Exp. Med. Biol. 2006, 572, 531-540. [PubMed]

34. Kaczara, P.; Sarna, T.; Burke, J.M. Dynamics of $\mathrm{H}_{2} \mathrm{O}_{2}$ availability to ARPE-19 cultures in models of oxidative stress. Free Radic. Biol. Med. 2010, 48, 1064-1070. [CrossRef] [PubMed]

35. Imamura, Y.; Noda, S.; Hashizume, K.; Shinoda, K.; Yamaguchi, M.; Uchiyama, S.; Shimizu, K.; Mizushima, Y.; Shirasawa, T.; Tsubota, K. Drusen, choroidal neovascularization, and retinal pigment epithelium dysfunction in SOD1-deficient mice: A model of age-related macular degeneration. Proc. Natl. Acad. Sci. USA 2006, 103, 11282-11287. [CrossRef] [PubMed]

36. Justilien, V.; Pang, J.-J.; Renganathan, K.; Zhan, X.; Crabb, J.W.; Kim, S.R.; Sparrow, J.R.; Houswirth, W.W.; Lewin, A.S. SOD2 knockdown mouse model of early AMD. Investig. Opthalmol. Vis. Sci. 2007, 48, 4407-4420. [CrossRef] [PubMed]

37. Khandhadia, S.; Lotery, A. Oxidation and age-related macular degeneration: Insights from molecular biology. Expert. Rev. Mol. Med. 2010, 12, e34. [CrossRef] [PubMed]

38. Chichili, G.R.; Nohr, D.; Frank, J.; Flaccus, A.; Fraser, P.D.; Enfissi, E.M.A.; Biesalski, H.K. Protective effects of tomato extract with elevated $\beta$-carotene levels on oxidative stress in ARPE-19 cells. Br. J. Nutr. 2006, 96, 643-649.

39. Kauppinen, A.; Niskanen, H.; Suuronen, T.; Kinnunen, K.; Salminen, A.; Kaarnirana, K. Oxidative stress activates NLRP3 inflammasomes in ARPE-19 cells-implications for age-related macular degeneration (AMD). Immunol. Lett. 2012, 147, 29-33. [CrossRef]

40. Lederman, M.; Hagbi-Levi, S.; Grunin, M.; Obolensky, A.; Berenshtein, E.; Banin, E.; Chowers, I. Degeneration modulates retinal response to transient exogenous oxidative injury. PLoS ONE. 2014, 9, e87751.

41. Jin, X.; Wang, C.; Wu, W.; Liu, T.; Ji, B.; Zhou, F. Cyanidin-3-glucoside alleviates 4-hydroxyhexenal-induced NLRP3 inflammasome activation via JNK-c-Jun/AP-1 pathway in human retinal pigment epithelial cells. J. Immunol. Res. 2018, 2018, 5604610. [CrossRef]

42. Moine, E.; Boukhallat, M.; Cia, D.; Jacquemot, N.; Guillou, L.; Durand, T.; Vercauteren, J.; Brabet, P.; Crauste, C. New lipophenols prevent carbonyl and oxidative stresses involved in macular degeneration. Free Radic. Biol. Med. 2021, 162, 367-382. [CrossRef]

43. Anderson, O.A.; Finkelstein, A.; Shima, D.T. A2E induces IL-1 $\beta$ production in retinal pigment epithelial cells via the NLRP3 inflammasome. PLoS ONE 2013, 8, e67263.

44. Nakajima, E.; Hammond, K.B.; Shearer, T.R.; Azuma, M. Activation of the mitochondrial caspase pathway and subsequent calpain activation in monkey RPE cells cultured under zinc depletion. Eye 2014, 28, 85-92. [CrossRef] [PubMed]

45. Wang, Y.; Shen, D.; Wang, V.M.; Yu, C.R.; Wang, R.X.; Tuo, J.; Chan, C.C. Enhanced apoptosis in retinal pigment epithelium under inflammatory stimuli and oxidative stress. Apoptosis 2012, 17, 1144-1155. [CrossRef] [PubMed]

46. Gao, J.; Cui, J.Z.; To, E.; Cao, S.; Matsubara, J.A. Evidence for the activation of pyroptotic and apoptototic pathways in RPE cells associated with NLRP3 inflammasome in the rodent eye. J. Neuro. Inflamm. 2018, 15, 15.

47. Booij, J.C.; Baas, D.C.; Beisekeeva, J.; Gorgels, T.G.; Bergen, A.A. The dynamic nature of Bruch's membrane. Prog. Retin. Eye. Res. 2010, 29, 1-18. [CrossRef] [PubMed]

48. Pikuleva, I.A.; Curcio, C.A. Cholesterol in the retina: The best is yet to come. Prog. Retin. Eye Res. 2014, 41, 64-89. [CrossRef]

49. Gass, J.D.M. Drusen and disciform macular detachment and degeneration. Arch. Ophthalmol. 1973, 90, 206-217. [CrossRef]

50. Findlay, Q.; Jobling, A.I.; Wessey, K.A.; Greferath, U.; Phipps, J.A.; Guymer, R.H.; Fletcher, E.L. Prophylactic laser in age-related macular degeneration: The past, the present and the future. Eye 2018, 32, 972-980. [CrossRef]

51. Frennesson, C.; Nilsson, S.E. Prophylactic laser treatment in early age related maculopathy reduced the incidence of exudative complications. Br. J. Ophthalmol. 1998, 82, 1169-1174. [CrossRef] 
52. Brinkmann, R.; Roider, J.; Birngruber, R. Selective retina therapy (SRT): A review on methods, techniques, preclinical and first clinical results. Bull. Soc. Belge. Ophthalmol. 2006, 302, 51-69.

53. Wood, J.P.M.; Plunkett, M.; Previn, V.; Chidlow, G.; Casson, R.J. Nanosecond pulse lasers for retinal applications. Lasers Surg. Med. 2011, 43, 499-510. [CrossRef]

54. Regan, J.D.; Parrish, J.A. The Science of Photomedicine; Plenum Press: London, UK, 1982.

55. Hong, E.J.; Choi, D.G.; Shim, M.S. Targeted and effective photodynamic therapy for cancer using functionalized nanomaterials. Acta. Pharm. Sin. B 2016, 6, 297-307. [CrossRef] [PubMed]

56. Mashayekhi, V.; Hoog, C.O.; Oliveira, S. Vascular targeted photodynamic therapy: A review of the efforts towards molecular targeting of tumor vasculature. J. Porphyrins. Phthalocyanines 2019, 23, 1229-1240. [CrossRef] [PubMed]

57. Van den Bergh, H. Photodynamic therapy of age-related macular degeneration history and principles. Semin. Ophthalmol. 2001, 16, 181-200. [CrossRef]

58. Giese, A.C. Historical Introduction. In Photophysiology, Volume I. General Principles; Action of Light on Plants; Academic Press Inc.: New York, NY, USA, 1964.

59. von Tappeiner, H.; Jesionek, A. Therapeutische versuchemit fluoreszierenden stoffen. Munch. Med. Wochenschr. 1903, 50, 2042-2044.

60. Figge, F.H.J.; Weiland, G.S.; Manganiello, L.O.J. Cancer detection and therapy. Affinity of neoplastic, embryonic, and traumatized tissues for porphyrins and metalloporphyrins. Proc. Soc. Exptl. Biol. Med. 1948, 68, 640-641. [CrossRef]

61. Dougherty, T.J.; Gomer, C.J.; Henderson, B.W.; Jori, G.; Kessel, D.; Korbelik, M.; Moan, J.; Peng, Q. Photodynamic therapy. J. Natl. Cancer Inst. 1998, 90, 889-905. [CrossRef] [PubMed]

62. Friedlander, M.; Theesfeld, C.L.; Sugita, M.; Fruttiger, M.; Thomas, M.A.; Chang, S.; Cheresh, D.A. Involvement of integrins alpha $\mathrm{v}$ beta 3 and alpha v beta 5 in ocular neovascular diseases. Proc. Natl. Acad. Sci. USA 1996, 93, 9764-9769. [CrossRef] [PubMed]

63. Tsuchida, T.; Zheng, G.; Pandey, R.K.; Potter, W.R.; Bellnier, D.A.; Henderson, B.W.; Kato, H.; Dougherty, T.J. Correlation between site II-specific human serum albumin (HAS) binding affinity and murine in vivo photosensitizing efficacy of some photofrin component. Photochem. Photobiol. 1997, 66, 224-228. [CrossRef]

64. Vrouenraets, M.B.; Visser, G.W.M.; Stewart, F.A.; Stigter, M.; Oppelaar, H.; Postmus, P.E.; Snow, G.B.; Van Dongen, G.A.M.S Development of meta-tetrahydroxyphenylchlorin-monoclonal antibody conjugates for photoimmunotherapy. Cancer Res. 1999, 59, 1505-1513. [PubMed]

65. Johnson, L.V.; Leitner, W.P.; Staples, M.K.; Anderson, D.H. Complement activation and inflammatory processes in drusen formation and age related macular degeneration. Exp. Eye Res. 2001, 73, 887-896. [CrossRef] [PubMed]

66. Swanson, M.W.; McGwin, G., Jr. Anti-inflammatory drug use and age-related macular degeneration. Optom. Vis. Sci. 2008, 85, 947-950. [CrossRef] [PubMed]

67. Apte, R.S. Regulation of angiogenesis by macrophages. Adv. Exp. Med. Biol. 2010, 664, 15-19. [PubMed]

68. Ponnusamy, C.; Sugumaran, A.; Krishnaswami, V.; Kandasamy, R.; Natesan, S. Design and development of artemisinin and dexamethasone loaded topical nanodispersion for the effective treatment of age-related macular degeneration. IET Nanobiotechnol. 2019, 13, 868-874. [CrossRef]

69. Ehmann, D.; Garcia, R. Triple therapy for neovascular age-related macular degeneration: Verteporfin PDT, bevacizumab, and dexamethasone. Retina 2007, 27, 133-140.

70. Francis, B.A.; Chang, E.L.; Haik, B.G. Particle size and drug interactions of injectable corticosteroids used in ophthalmic practice. Ophthalmology 1996, 103, 1884-1888. [CrossRef]

71. Jonas, J.B.; Libondi, T.; Golubkina, L.; Spandau, U.H.; Schlichtenbrede, F.; Rensch, F. Combined intravitreal bevacizumab and triamcinolone in exudative age-related macular degeneration. Acta Ophthalmol. 2010, 88, 630-634. [CrossRef] [PubMed]

72. Zhao, M.; Mantel, I.; Gelize, E.; Li, X.; Xie, X.; Arboleda, A.; Seminel, M.; Levy-Boukris, R.; Derngoghossian, M.; Prunotto, A.; et al. Mineralocorticoid receptor antagonism limits experimental choroidal neovascularization and structural changes associated with neovascular age-related Macular degeneration. Nat. Commun. 2019, 10, 369. [CrossRef]

73. Christen, W.G.; Glynn, R.J.; Chew, E.Y.; Burning, J.E. Low-dose aspirin and medical record-confirmed age-related macular degeneration in a randomized trial of women. Ophthalmology 2009, 116, 2386-2392. [CrossRef]

74. Ye, J.; Xu, Y.F.; He, J.J.; Lou, L.X. Association between aspirin use and age-related macular degeneration: A meta-analysis. Investig. Ophthalmol. Vis. Sci. 2014, 55, 2687-2696. [CrossRef]

75. McGeer, P.L.; Sibley, J. Sparing of age-related macular degeneration in rheumatoid arthritis. Neurobiol. Aging. 2005, 26, 1199-1203. [CrossRef]

76. Gamache, D.A.; Graff, G.; Brady, M.T.; Spellman, J.M.; Yanni, J.M. Nepafenac, a unique nonsteroidal prodrug with potential utility in the treatment of trauma-induced ocular inflammation: I. Assessment of anti-inflammatory efficacy. Inflammation 2000, 24, 357-370. [CrossRef]

77. Baranano, D.E.; Kim, S.J.; Edelhauser, H.F.; Durairaj, C.; Kompella, U.B.; Handa, J.T. Efficacy and pharmacokinetics of intravitreal non-steroidal anti-inflammatory drugs for intraocular inflammation. Br. J. Ophthalmol. 2009, 93, 1387-1390. [CrossRef] [PubMed]

78. Hitner, H.; Nagle, B. Chapter 25. Respiratory Pharmacology, Treatment of Asthma and COPD. In Pharmacology: An Introduction, 7th ed.; McGraw Hill Education Korea, Ltd. and Medical Science: Seoul, Korea, 2019; pp. 385-402.

79. Kim, S.J.; Flach, A.J.; Jampol, L.M. Nonsteroidal anti-inflammatory drugs in ophthalmology. Surv. Ophthalmol. 2010, 55, 108-133. [CrossRef] 
80. Ferrara, N.; Kerbel, R.S. Angiogenesis as a therapeutic target. Nature 2005, 438, 967-974. [CrossRef] [PubMed]

81. Miller, J.; Adamis, A.P.; Shima, D.T.; D'Amore, P.A.; Moulton, R.S.; O’Reilly, M.S.; Folkman, J.; Dvorak, H.F.; Brown, L.F.; Berse, B.; et al. Vascular endothelial growth factor/vascular permeability factor is temporally and spatially correlated with ocular angiogenesis in a primate model. Am. J. Pathol. 1994, 145, 574-584. [CrossRef] [PubMed]

82. Kim, R. Introduction, mechanism of action and rationale for anti-vascular endothelial growth factor drugs in age-related macular degeneration. Indian J. Ophthalmol. 2007, 55, 413-415. [CrossRef]

83. Lu, M.; Adamis, A.P. Molecular biology of choroidal neovascularization. Ophthalmol. Clin. N. Am. 2006, 19, 323-334.

84. Noel, A.; Jost, M.; Lambert, V.; Lecomte, J.; Rakic, J.M. Anti-angiogenic therapy of exudative age-related macular degeneration: Current progress and emerging concepts. Trends Mol. Med. 2007, 13, 345-352. [CrossRef]

85. Jemni-Damer, N.; Guedan-Duran, A.; Fuentes-Andion, M.; Serrano-Bengoechea, N.; Alfageme-Lopez, N.; Armada-Maresca, F.; Guinea, G.V.; Perez-Rigueiro, J.; Rojo, F.; Gonzalez-Nieto, D.; et al. Biotechnology and biomaterial-based therapeutic strategies for age-related macular degeneration. Part I: Biomaterials-based drug delivery devices. Bioeng. Biotechnol. 2020, 8, 549089.

86. Ferrara, N.; Hillan, K.J.; Gerber, H.P.; Novotny, W. Discovery and development of bevacizumab: An anti-VEGF antibody for treating cancer. Nat. Rev. Drug. Discov. 2004, 3, 391-400. [CrossRef]

87. Freund, K.B.; Mrejen, S.; Gallego-Pinazo, R. An update on the pharmacotheraphy of neovascular age-related macular degeneration. Expert Opin. Pharm. 2013, 14, 1017-1028. [CrossRef]

88. Chen, Y.; Wiesmann, C.; Fuh, G.; Li, B.; Christinger, H.W.; McKay, P.; De Vos, A.M.; Lowman, H.B. Selection and analysis of an optimized anti-VEGF antibody: Crystal structure of an affinity-matured Fab in complex with antigen. J. Mol. Biol. 1999, 293, 865-881. [CrossRef]

89. Adamis, A.P.; Shima, D.T. The role of vascular endothelial growth factor in ocular health and disease. Retina. 2005, 25, 111-118. [CrossRef] [PubMed]

90. Vinores, S.A. Pegaptanib in the treatment of wet, age-related macular degeneration. Int. J. Nanomed. 2006, 1, $263-268$.

91. Trichonas, G.; Kaiser, P.K. Aflibercept for the treatment of age-related macular degeneration. Ophthalmol. Ther. 2013, 2, 89-98. [CrossRef]

92. Heier, J.S.; Brown, D.M.; Chong, V.; Korobelnik, J.F.; Kaiser, P.K.; Nguyen, Q.D.; Kirchhof, B.; Ho, A.; Ogura, Y.; Yancopoulos, G.D.; et al. Intravitreal Aflibercept (VEGF Trap-Eye) in wet age-related macular degeneration. Ophthalmology 2012, 119, 2537-2548. [CrossRef]

93. Hu-Lowe, D.D.; Zou, H.Y.; Grazzini, M.L.; Hallin, M.E.; Wickman, G.R.; Amundson, K.; Chen, J.H.; Rewolinski, D.A.; Yamazaki, S.; Wu, E.Y.; et al. Nonclinical antiangiogenesis and antitumor activities of axitinib (AG-013736), an oral, potent, and selective inhibitor of vascular endothelial growth factor receptor tyrosine kinases 1, 2, 3. Clin. Cancer Res. 2008, 14, 7272-7283. [CrossRef] [PubMed]

94. Kang, S.; Roh, C.R.; Cho, W.K.; Park, K.C.; Yang, K.J.; Choi, H.S.; Kim, S.H.; Roh, Y.J. Antiangiogenic effects of axitinib, an inhibitor of vascular endothelial growth factor receptor tyrosine kinase, on laser-induced choroidal neovascularization in mice. Curr. Eye Res. 2013, 38, 119-127. [CrossRef] [PubMed]

95. Zhang, X.; Zhu, M.; Xie, L.; Sun, X.; Xu, J.; Guo, Y.; Liu, D.; Shi, Y.; Xu, X.; Song, E. Cabozantinib, a multityrosine kinase inhibitor of MET and VEGF receptors which suppresses mouse lase-induced choroidal neovascularization. J. Ophthalmol. 2020, 2020, 5905269. [CrossRef]

96. Kernt, M.; Thiele, S.; Hirneiss, C.; Neubauer, A.S.; Lackerbauer, C.A.; Wolf, A.; Eibl, K.H.; Haritoglou, C.; Ulbig, M.W.; Kampik, A. Cytoprotective and antiangiogenetic effects of the multikinase inhibitor sorafenib on human retinal pigment epithelium. Ophthalmologe 2011, 108, 445-451. [CrossRef] [PubMed]

97. Thiele, S.; Liegl, R.G.; Konig, S.; Siedlecki, J.; Langer, J.; Eibl, K.; Haritoglou, C.; Kampik, A.; Kernt, M. Multikinase inhibitors as a new approach in neovascular age-related macular degeneration (AMD) treatment: In vitro safety evaluations of axitinib, pazopanib and sorafenib for intraocular use. Klin. Monbl. Augenheilkd. 2013, 230, 247-254.

98. Takahashi, H.; Obata, R.; Tamaki, Y. A novel vascular endothelial growth factor receptor inhibitor, SU11248, suppresses choroidal neovascularization in vivo. J. Ocul harmacol. Ther. 2006, 22, 213-218. [CrossRef] [PubMed]

99. Nowak-Sliwinska, P.; Weiss, A.; Van Beijnum, J.R.; Wong, T.J.; Ballini, J.P.; Lovisa, B.; Van den Bergh, H.; Griffioen, A.W. Angiostatic kinase inhibitors to sustain photodynamic angio-occlusion. J. Cell Mol. Med. 2012, 16, 1553-1562. [CrossRef] [PubMed]

100. Subczynski, W.K.; Wisniewska, A.; Widomska, J. Location of macular xanthophylls in the most vulnerable regions of photoreceptor outer-segment membranes. Arch. Biochem. Biophys. 2010, 504, 61-66. [CrossRef] [PubMed]

101. Perry, A.; Rasmussen, H.; Johnson, E.J. Xanthophyll (lutein, zeaxanthin) content of fruits, vegetables and corn and egg products. J. Food. Comp. Anal. 2009, 22, 9-15. [CrossRef]

102. Koushan, K.; Rusovici, R.; Li, W.; Ferguson, L.R.; Chalam, K.V. The role of lutein in eye-related disease. Nutrients 2013, 5, 1823-1839. [CrossRef]

103. Liu, H.; Liu, W.; Zhou, X.; Long, C.; Kuang, X.; Hu, J.; Tang, Y.; Liu, L.; He, J.; Huang, Z.; et al. Protective effect of lutein on ARPE-19 cells upon $\mathrm{H}_{2} \mathrm{O}_{2}$-induced $\mathrm{G}_{2} / \mathrm{M}$ arrest. Mol. Med. Rep. 2017, 16, 2069-2074. [CrossRef]

104. Kim, D.H.; Choi, Y.R.; Shim, J.; Choi, Y.S.; Kim, Y.T.; Kim, M.K.; Kim, M.J. Suppressive effect of Arctium lappa L. leaves on retinal damage against A2E-induced ARPE-19 cells and mice. Molecules 2020, 25, 1737. [CrossRef] 
105. Zhao, H.; Wang, R.; Ye, M.; Zhang, L. Genipin protects against $\mathrm{H}_{2} \mathrm{O}_{2}$-induced oxidative damage in retinal pigment epithelial cells by promoting Nrf2 signaling. Int. J. Mol. Med. 2019, 43, 936-944. [CrossRef]

106. Kong, J.M.; Chia, L.S.; Goh, N.K.; Chia, T.F.; Brouillard, R. Analysis and biological activities of anthocyanins. Phytochemistry 2003, 64, 923-933. [CrossRef]

107. Ni, T.; Yang, W.; Xing, Y. Protective effects of delphinidin against $\mathrm{H}_{2} \mathrm{O}_{2}$-induced oxidative injuries in human retinal pigment epithelial cells. Biosci. Rep. 2019, 39, BSR20190689. [CrossRef]

108. Aung, K.H.; Liu, H.; Ke, Z.; Jiang, S.; Huang, J. Glabridin attenuates the retinal degeneration induced by sodium iodate in vitro and in vivo. Front. Pharmacol. 2020, 11, 566699. [CrossRef]

109. Chen, C.; Guo, D.; Lu, G. Wogonin protects human retinal pigment epithelium cells from LPS-induced barrier dysfunction and inflammatory responses by regulating the TLR4/NF-kB signaling pathway. Mol. Med. Rep. 2017, 15, 2289-2295. [CrossRef] [PubMed]

110. Kim, J.; Cho, K.; Choung, S.Y. Protective effect of Prunella vulgaris var. L extract against blue light induced damages in ARPE-19 cells and mouse retina. Free Radic. Biol. Med. 2020, 152, 622-631. [CrossRef] [PubMed]

111. Yoon, S.M.; Lee, B.L.; Guo, Y.R.; Choung, S.Y. Preventive effect of Vaccinium uliginosum L. extract and its fractions on age-related macular degeneration and its action mechanisms. Arch. Pharm. Res. 2016, 39, 21-32. [CrossRef]

112. Sun, H.J.; Jin, X.M.; Xu, J.; Xiao, Q. Baicalin alleviates age-related macular degeneration via miR-223/NLRP3-regulated pyroptosis. Pharmacology 2020, 105, 28-38. [CrossRef] [PubMed]

113. Marti, R.; Rosello, S.; Cebolla-Cornejo, J. Tomato as a source of carotenoids and polyphenols targeted to cancer prevention. Cancer 2016, 8, 58. [CrossRef] [PubMed]

114. Chiang, J.Y.L. Bile acids: Regulation of synthesis. J. Lipid Res. 2009, 50, 1955-1966. [CrossRef] [PubMed]

115. Hofmann, A.F. The continuing importance of Bile Acids in liver and intestinal disease. Arch. Intern. Med. 1999, 159, 2647-2658. [CrossRef]

116. Warden, C.; Barnett, J.M.; Brantley, M.A., Jr. Taurocholic acid inhibits features of age-related macular degeneration in vitro. Exp. Eye Res. 2020, 193, 107974. [CrossRef] [PubMed]

117. World Population Ageing. Available online: https://www.un.org/en/development/desa/population/publications/pdf/ ageing/WPA2017_Highlights.pdf (accessed on 1 October 2021).

118. Mainster, M.A.; Reichel, E. Transpupillary thermotherapy for age-related macular degeneration: Long-pulse photocoagulation, apoptosis, and heat shock proteins. Ophthalmic. Surg. Lasers 2000, 31, 359-373. [CrossRef]

119. Bresnick, G.H. Diabetic maculopathy. A critical review highlighting diffuse macular edema. Ophthalmol. 1983, 90, $1301-1317$. [CrossRef]

120. Butler, M.C.; Itotia, P.N.; Sullivan, J.M. A high-throughput biophotonics instrument to screen for novel ocular photosensitizing therapeutic agents. Investig. Ophthalmol. Vis. Sci. 2010, 51, 2705-2720. [CrossRef] [PubMed]

121. Kapugi, M.; Cunningham, K. Corticosteroids. Orthop. Nurs. 2019, 38, 336-339. [CrossRef] [PubMed]

122. Wang, Y.; Wang, V.M.; Chan, C.C. The role of anti-inflammatory agents in age-related macular degeneration (AMD) treatment. Eye 2011, 25, 127-139. [CrossRef] [PubMed]

123. Falavarjani, K.G.; Nguyen, Q.D. Adverse events and complications associated with intravitreal injection of anti-VEGF agents: A review of literature. Eye 2013, 27, 787-794. [CrossRef] [PubMed]

124. Ramasubramanian, A.; Shields, C.L. Bevacizumab for Coats' disease with exudative retinal detachment and risk of vitreoretinal traction. Br. J. Ophthalmol. 2012, 96, 356-359. [CrossRef] [PubMed] 